Zagazig J. Agric. Res., Vol. 43 No. (3) 2016

http:/www.journals.zu.edu.eg/journalDisplay.aspx?Journalld=1\&queryType=Master

\title{
APPLICATION OF SIMPLE SEQUENCE REPEAT (SSR) MARKER TO DIFFERENTIATE AMONG EIGHT BARLEY VARIETIES
}

\author{
Rasha Y.S. Abd El-Khalek* \\ Seed Tech. Res. Dept., Field Crops Res. Inst., ARC., Giza, Egypt
}

\begin{abstract}
The present investigation was carried out to identity eight barley varieties using DNA fingerprinting detected by (SSR)-PCR molecular markers and SDS- PAGA protein electrophoresis. Twelve anchored SSR primers were used for fingerprinting of the eight barley varieties and 76 bands were detected, from which 56 bands (74\%) were polymorphic. Giza 125 variety produced the largest number of markers. It produced 14 band markers in seven primers (SSR 1, SSR 4, SSR 5, SSR 6, SSR 7, SSR 11 and SSR 12). Giza 123 variety produced five bands in three primers (SSR 5, SSR 8 and SSR 12). Giza 127 produced four bands in three primers (SSR 5, SSR 8 and SSR 9). Giza 124 produced two bands in two primers (SSR 2 and SSR 8). Also Giza 132 variety produced two bands in two primers (SSR 9 and SSR 11). Giza 129 variety has one band marker in primer SSR 8. On the other hand, the results of protein electrophoresis revealed that, total number of bands was 13, out of which 7 bands $(54 \%)$ were polymorphic. Protein electrophoresis produced four marker bands, three of them were found in variety Giza 124 and one in variety Giza 129. Existing genetic differences between varieties are of great importance from the point of view of the breeder to take advantage in barley improvement programs.
\end{abstract}

Key words:Barley, Hordeum vulgare, L. polyacrylamide gel electrophoresiss (SDS-PAGE), simple sequence repeat (DNA-SSR)

\section{INTRODUCTION}

Barely, Hordeum vulgare L. is recognized as one of the most economic and important cereals in the world, by area and production ranked as the fourth most important cultivated crop. Following wheat, rice and maize, it can be grown in a wide range of environmental conditions. Barley, is one of the principal cereal crops in the world and is cultivated in all temperate areas (Von Bothmer et al., 1995). Sodium dodecyl sulphate polyacrylamide gel electrophorsiss (SDS-PAGE) is most economical simple and extensively used biochemical technique for analysis of genetic structure of germplasm. Gel electrophoresis can directly equate variation in protein banding patterns to gene coding various proteins and proved to be useful in revealing polymorphic loci that encode isozymes or proteins (Masoje et al., 2001). Seed storage protein markers and molecular markers have been used as tools to enhance barley variety identification capabilities for several years. Among different methods of molecular markers, SSR markers have proved to be markers of choice for several applications in breeding because of their multi-allelic nature for having Codominant inheritance reproducibility, abundance and wide genomic distribution (Gupta and Varshney, 2000).

Multilocus fingerprinting methods based on the polymerase chain reaction (PCR) have been extensively used to study the relationships among varieties and varieties of many different plants. The most informative polymorphic marker system currently available is microsatellite or sample sequence repeat (SSRs) (Tantz and Renz, 1984). Various molecular marker techniques have been developed into powerful tools for diversity analysis and

\footnotetext{
* Corresponding author: Tel. : +200114 2437717

E-mail address: yabdelkhalek@gmail.com
} 
establishing relationships between varieties. Codominant markers have become important genetic markers in a wide range of crop species, including barley (Struss and Plieske, 1988). SSR marker is abundant dispersed throughout the genome and show higher levels of polymorphism than other genetic markers (Russel et al., 1997). Their feature coupled with their ease of detection have made them useful molecular markers for this reason SSR markers are ideal for distinguishing and identification of accessions that are genetically very similar (Saker et al., 2005). Their potential for automation and their inheritance in a codominant manner are additional advantages when compared to other types of molecular markers. Up to 37 different alleles for one SSR locus have been found in barley (Saghai-Maroof et al., 1994).

\section{MATERIALS AND METHODS}

The present study was carried out at the Department of Seed Technology Research, Field Crops Research Institute, ARC during 2014. Barley genotypes included eight varieties as shown in Table 1.

\section{Electrophoresis of Total Proteins}

Total proteins were extracted from seeds and SDS-PAGE was performed according to the protocol described by Laemmli (1970).

\section{Molecular Markers}

SSR-PCR analyses: Twelve SSR primers were used to evaluate the eight barley varieties as shown in Table 2.

\section{Plant Material and DNA Extraction}

For genomic DNA isolation, seeds of each barely variety were germinated and grown to the four-leaf stage. The seedlings were used for DNA extraction by DNeasy plant minikit (Quigen Inc., Cat.no.69104, and USA). The DNA concentration of the final samples was measured by ultraviolet (UV) spectrophotometer at $260 \mathrm{~nm}$. The integrity of the DNA was checked out by electrophoresis in a $1 \%$ agarose gel in TAE buffer.

\section{Polymerase Chain Reaction (PCR) Conditions}

DNA amplification was carried out in PCR tubes containing $25 \mu \mathrm{L}$ reaction mixture, having
$1 \mu \mathrm{L}$ template DNA, $1 \mu \mathrm{L}$ SSR primer, $15 \mu \mathrm{L}$ of dd $\mathrm{H}_{2} \mathrm{O}$ and $7 \mu \mathrm{L}$ PCR mix. Amplification was carried out in a PTC- 200 thermal cycler (MJ Research, Watertown, USA) programmed as follows: The temperature profile consisted of an initial denaturation step of DNA at $94^{\circ} \mathrm{C}$ for 2 min, followed by 35 cycles: $94^{\circ} \mathrm{C}$ for $45 \mathrm{sec}$., $57-65^{\circ} \mathrm{C}$ for $1 \mathrm{~min}$, and $72^{\circ} \mathrm{C}$ for $1 \mathrm{~min} 30 \mathrm{sec}$. Annealing temperatures were optimized individually for each SSR (listed in Table 1). After the final cycle, samples were incubated at $72^{\circ} \mathrm{C}$ for $10 \mathrm{~min}$ to ensure complete extension.

\section{Gel Electrophoresis}

Gel electrophoresis was applied according to Sambrook et al. (1989). The run was performed for one hour at 80 volt in pharmacia submarine $(20 \times 20 \mathrm{~cm})$. Bands were detected on UVtransilluminator and photographed by Gel documentation 2000, Bio- Rad. Fragment size of SSR was estimated from the gel by comparison with the $100+1.5 \mathrm{~kb}$ ladder marker. The bands were recorded as either present or absent into a database of " 1 "and " 0 ".

\section{RESULTS AND DISCUSSION}

\section{Biochemical Analysis by Protein Electrophoresis}

The SDS-PAGE patterns for total soluble proteins in the eight barley varieties are shown in Fig. 1 and Table 3. All markers were scored for presence/absence (+/-). A maximum number of 13 bands, were detected with molecular weights (mw) ranged from 380 to $80 \mathrm{KDa}$ and 7 of them were polymorphic (54\% polymorphism). Band with MW of about 380, 330 and $299 \mathrm{KDa}$ could be considered as a positive marker of Giza 124 variety, which was present only in this variety but absent in all other varieties under study, while band on MW 190 KDa was present only in barley variety Giza 129. This band is considered positive specific marker for this variety. The genetic diversity in barley varieties have been addressed by using biochemical evidence derived by the electrophoresis separation of the seed protein (Facciol et al., 1999). Karimzadeh et al. (2006) observed changes in the electrophoresis pattern of water soluble proteins from barley varieties, also Ali et al. (2007) identified 12 polymorphic bands with different expressions in six barley genotypes. 
Table 1. Number and name of eight barley varieties

\begin{tabular}{llcl}
\hline No. & Variety & Row type & \multicolumn{1}{c}{ Pedigree } \\
\hline $\mathbf{1}$ & Giza 123 & 6R & Giza 117/FAO 86 \\
$\mathbf{2}$ & Giza 124 & 6R & Giza 117//Bahteem 52// Giza 118/FAO 86 \\
$\mathbf{3}$ & Giza 125 & 6R & Sisterr line to Giza 124 \\
$\mathbf{4}$ & Giza 126 & 6R & Baladi Bathteem/SD 729-Por 12762-BC \\
$\mathbf{5}$ & Giza 127 & 2R & WI2291"/Bags"//Harm/al-02" \\
$\mathbf{6}$ & Giza 129 & 6R & Deir Alla 106/Cel//As46/Aths*2 \\
$\mathbf{7}$ & Giza 132 & 6R & Rihane-05//As 46/Aths/Lignee 686 \\
$\mathbf{8}$ & Giza 2000 & 6R & Giza 121/Giza 124 \\
\hline
\end{tabular}

Table 2. Name and sequence of SSR primers which were used for SSR-PCR analyses

\begin{tabular}{|c|c|}
\hline Primer name & Sequence \\
\hline \multirow[t]{2}{*}{$\overline{\text { SCindo2587- SSR } 1}$} & Forward 5’GGT GAC CCA GCC AAA TTT TA3’ \\
\hline & Reverse5' GCA GCT GCT AGT TGG TTC ATC3' \\
\hline \multirow[t]{2}{*}{ SCind60002- SSR 2} & Forward 5’CAT CAT CAC GCC ACC ATA CT3' \\
\hline & Reverse 5'CGA ATG CAG TAC AGC CTC AG3' \\
\hline \multirow[t]{2}{*}{ Bmag0211- SSR 3} & Forward 5’ACA TCA TGT CGA TCA AAG C3' \\
\hline & Reverse 5' ATT CAT CGA TCT TGT ATT AGT CC3' \\
\hline \multirow[t]{2}{*}{ HVm4- SSR 4} & Forward 5'GCA AAG TCG TCG AAG GAG3' \\
\hline & Reverse 5'CCA GTC CAA TGG CAT CTA CA3' \\
\hline \multirow[t]{2}{*}{ HVLTPP- SSR 5} & Forward 5'CAA AGT ACA ACA AAC TCA CGA3' \\
\hline & Reverse 5'AGA CGC TGA GTA CGT TGA G3' \\
\hline \multirow[t]{2}{*}{ HVHVA1- SSR 6} & Forward 5' CGA CCA AAC ACG ACG ACT AAA GGA3' \\
\hline & Reverse 5' CAT GGG AGG GGA CAA CAC3' \\
\hline \multirow[t]{2}{*}{ Bmac0018-SSR 7} & Forward 5' GTC CTT TAC GCA TGA ACC GT3' \\
\hline & Reverse 5' ACA TAC GCC AGA CTC GTG TG3' \\
\hline \multirow[t]{2}{*}{ EBmac070- SSR 8} & Forward 5’TGG CAC TAA AGC AAA AGA C3' \\
\hline & Reverse 5' ATG ATG AGA ACT CTT CAC CC3' \\
\hline \multirow[t]{2}{*}{ Scind16991-SSR 9} & Forward 5' GGG CTT CCC CTC CTT TGT AT3' \\
\hline & Reverse 5'CGC CGT TCC AGT TTA ACT TC3' \\
\hline \multirow[t]{2}{*}{ HVm40- SSR10 } & Forward 5'CGA TTC CCC TTT TCC CAC3' \\
\hline & Reverse 5' ATT CTC CGC CGT CCA CTC3' \\
\hline \multirow[t]{2}{*}{ EBmag041-SSR 11} & Forward 5' AAA CAG CAG CAA GAG GAG3' \\
\hline & Reverse 5'GAA ACC CAT CAT AGC AGC3' \\
\hline \multirow[t]{2}{*}{ HVm36-SSR 12} & Forward 5’ TCC AGC CGA CAA TTT CTT G3’ \\
\hline & Reverse 5' AGT ACT CCG ACA CCA CGT CC3' \\
\hline
\end{tabular}




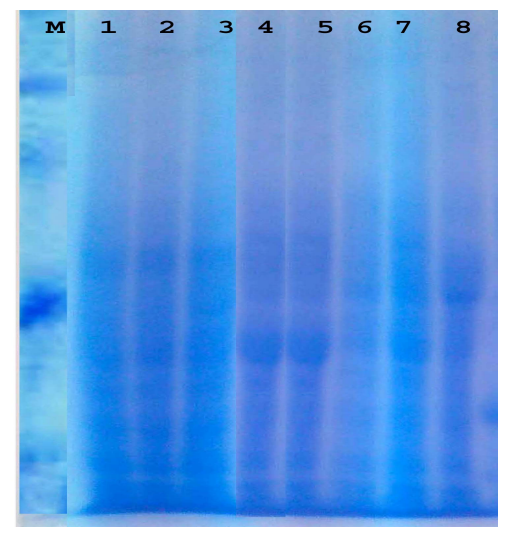

Fig. 1. SDS-PAGE profiles of eight barley varieties

Table 3. SDS-PAGE of total seed protein in eight barley varieties

\begin{tabular}{|c|c|c|c|c|c|c|c|c|c|}
\hline Band number & MW & Giza 123 & Giza 124 & Giza 125 & Giza 126 & Giza 127 & Giza 129 & Giza 132 & Giza 2000 \\
\hline 1 & 380 & - & + & - & - & - & - & - & - \\
\hline 2 & 330 & - & + & - & - & - & - & - & - \\
\hline 3 & 299 & - & + & - & - & - & - & - & - \\
\hline 4 & 265 & + & + & + & + & + & + & + & + \\
\hline 5 & 240 & - & - & - & - & + & + & + & + \\
\hline 6 & 230 & + & + & + & + & - & - & - & - \\
\hline 7 & 200 & + & + & + & + & + & + & + & + \\
\hline 8 & 190 & - & - & - & - & - & + & - & - \\
\hline 9 & 170 & + & + & + & + & + & + & + & + \\
\hline 10 & 140 & + & + & + & + & + & + & + & + \\
\hline 11 & 110 & + & - & + & + & + & + & - & + \\
\hline 12 & 90 & + & + & + & + & + & + & + & + \\
\hline 13 & 80 & + & + & + & + & + & + & + & + \\
\hline
\end{tabular}

Molecular analysis of eight barley varieties using Simple Sequence Repeat (SSR) markers

For SSR analysis, DNA of eight barley varieties were subjected to PCR against 12 specific primers of SSR as described in Fig. 2 and illustrated in Table 4 . Total number of bands were 76 bands, 56 of them were polymorphic (74\% polymorphism). The highest number of bands were shown in primers SSR 5, SSR 8 and SSR 9 (9 bands) while, the lowest one was obtained in primer SSR 3 (2 bands) and SSR 7 (3 bands). On the other hand, only primer SSR 9 generated no monomorphic bands $(100 \%$ polymorphism), while the lowest polymorphism was $0 \%$ detected in primer SSR 3 as shown in Table 4.

Primer SSR1 produced 8 bands 6 of them were polymorphic (75\% polymorphism). This analysis indicated the presence of six positive markers for Giza 125 variety. Primer SSR2 showed 4 bands; three of them were polymorphic ( $75 \%$ polymorphism), this primer (SSR2) indicated the presence of one marker for Giza 124 variety. Primer SSR3 yielded 2 monomorphic bands ( $0 \%$ polymorphism). Primer SSR 4 revealed 6 bands; 4 of them were polymorphic ( $67 \%$ polymorphism) indicated the 


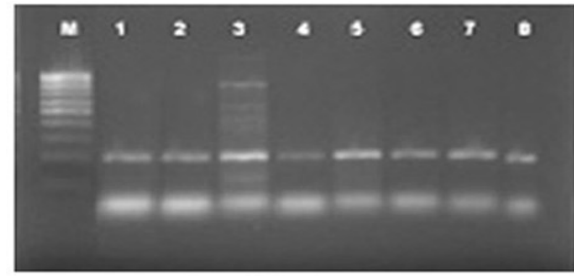

SSR 1

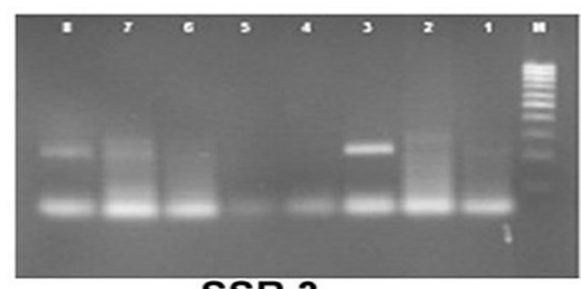

SSR 3

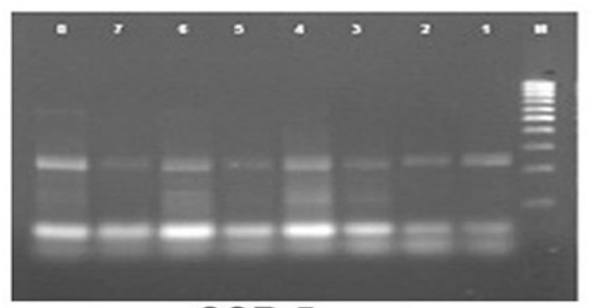

SSR 5

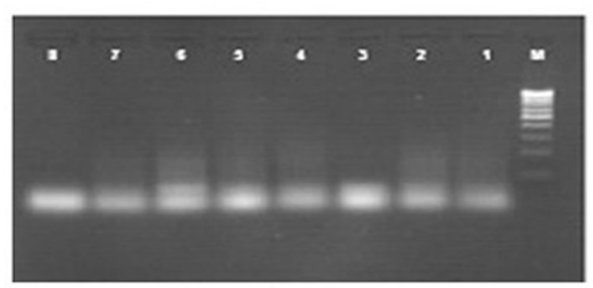

SSR 7

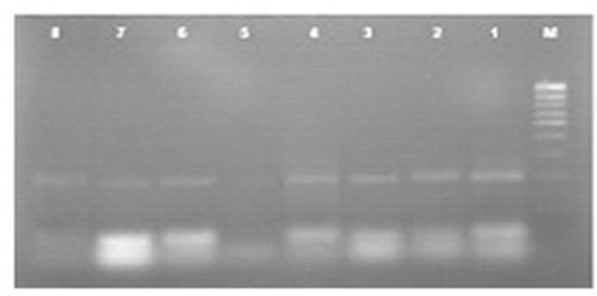

SSR 9

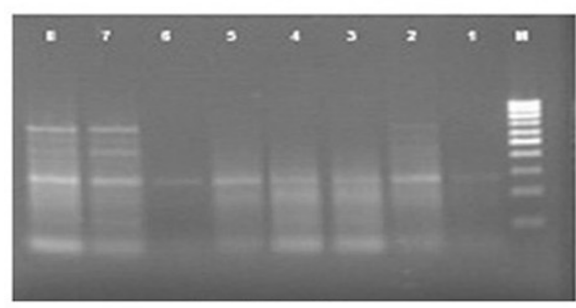

SSR 11

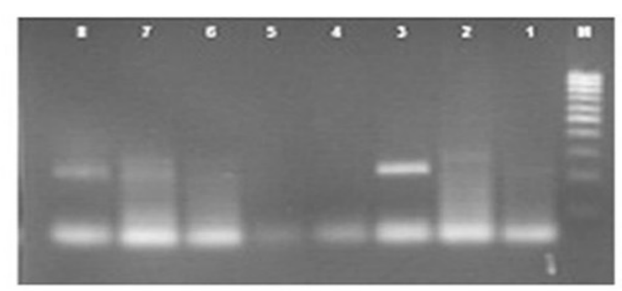

SSR 2
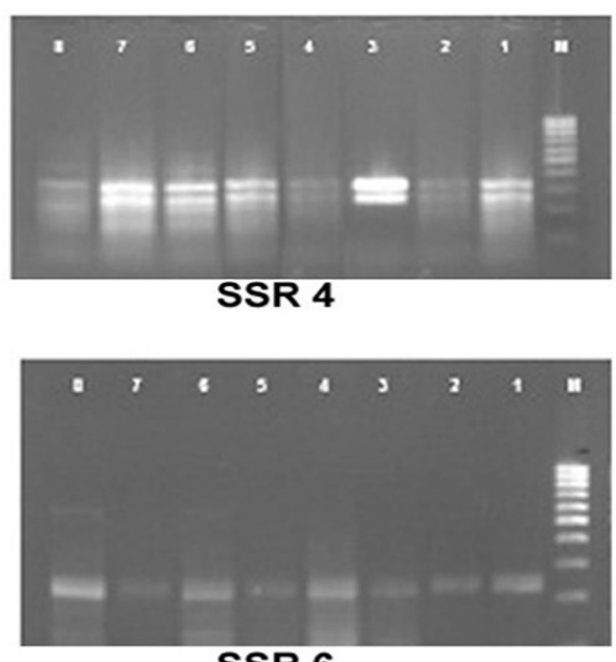

SSR 6

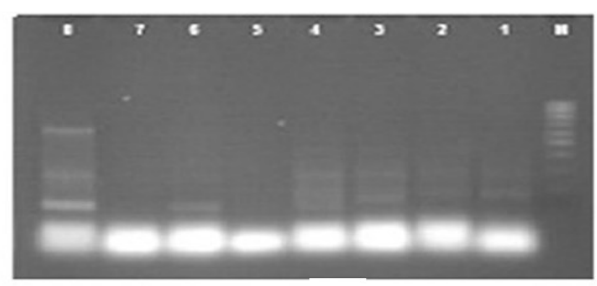

SSR 8

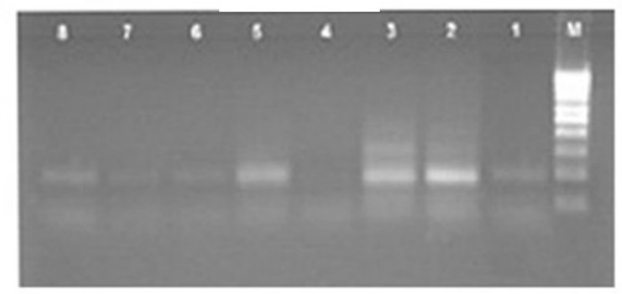

SSR 10

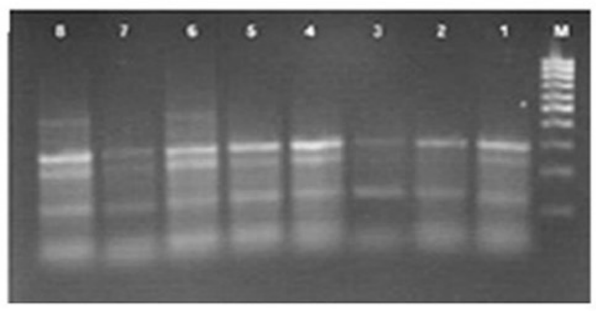

SSR 12

Fig. 2. SSR banding patterns amplified with 12 primers 
Table 4. Levels of polymorphism and unique genotypes specific bands for eight barley varieties by 12 SSR primers

\begin{tabular}{|c|c|c|c|c|c|c|}
\hline \multirow{2}{*}{$\begin{array}{c}\text { Band } \\
\text { Primer }\end{array}$} & \multirow{2}{*}{$\begin{array}{r}\text { Total } \\
\text { bands }\end{array}$} & \multirow{2}{*}{$\begin{array}{c}\text { Polymorphic } \\
\text { bands }\end{array}$} & \multirow{2}{*}{$\begin{array}{c}\text { Monomorphic } \\
\text { Bands }\end{array}$} & \multirow{2}{*}{$\begin{array}{c}\text { Polymorphism } \\
(\%)\end{array}$} & \multicolumn{2}{|c|}{ Unique bands } \\
\hline & & & & & Genotype & MW \\
\hline \multirow[t]{6}{*}{ SSR 1} & 8 & 6 & 2 & 75 & Giza 125 & $1470 \mathrm{bp}$ \\
\hline & & & & & & $870 \mathrm{bp}$ \\
\hline & & & & & & $515 \mathrm{bp}$ \\
\hline & & & & & & $405 \mathrm{bp}$ \\
\hline & & & & & & $355 \mathrm{bp}$ \\
\hline & & & & & & $115 \mathrm{bp}$ \\
\hline SSR 2 & 4 & 3 & 1 & 75 & Giza 124 & $250 \mathrm{bp}$ \\
\hline SSR 3 & 2 & 0 & 2 & 0 & 0 & 0 \\
\hline SSR 4 & 6 & 4 & 2 & 67 & Giza 125 & $525 \mathrm{bp}$ \\
\hline \multirow[t]{4}{*}{ SSR 5} & 9 & 7 & 2 & 78 & Giza 123 & $550 \mathrm{bp}$ \\
\hline & & & & & & $220 \mathrm{bp}$ \\
\hline & & & & & Giza 125 & $530 \mathrm{bp}$ \\
\hline & & & & & Giza 127 & $102 \mathrm{bp}$ \\
\hline \multirow[t]{3}{*}{ SSR 6} & 7 & 5 & 2 & 71 & Giza 125 & $725 \mathrm{bp}$ \\
\hline & & & & & & $560 \mathrm{bp}$ \\
\hline & & & & & & $460 \mathrm{bp}$ \\
\hline SSR 7 & 3 & 1 & 2 & 33 & Giza 125 & $230 \mathrm{bp}$ \\
\hline \multirow[t]{6}{*}{ SSR 8} & 9 & 8 & 1 & 89 & Giza 123 & $580 \mathrm{bp}$ \\
\hline & & & & & & $265 \mathrm{bp}$ \\
\hline & & & & & Giza 124 & $120 \mathrm{bp}$ \\
\hline & & & & & Giza 127 & $190 \mathrm{bp}$ \\
\hline & & & & & & $180 \mathrm{bp}$ \\
\hline & & & & & Giza 129 & $170 \mathrm{bp}$ \\
\hline \multirow[t]{3}{*}{ SSR 9} & 9 & 9 & 0 & 100 & Giza 127 & $255 \mathrm{bp}$ \\
\hline & & & & & Giza 132 & $205 \mathrm{bp}$ \\
\hline & & & & & Giza 2000 & $200 \mathrm{bp}$ \\
\hline SSR 10 & 4 & 2 & 2 & 50 & 0 & 0 \\
\hline \multirow[t]{2}{*}{ SSR 11} & 8 & 7 & 1 & 88 & Giza 125 & $65 \mathrm{bp}$ \\
\hline & & & & & Giza 132 & $560 \mathrm{bp}$ \\
\hline \multirow[t]{2}{*}{ SSR 12} & 7 & 4 & 3 & 57 & Giza 123 & $415 \mathrm{bp}$ \\
\hline & & & & & Giza 125 & $450 \mathrm{bp}$ \\
\hline Total & 76 & 56 & 20 & 74 & & \\
\hline
\end{tabular}


presence of one marker in variety Giza 125. Primer SSR5 revealed 9 bands 7 of them were polymorphic (78\% polymorphism) This primer has four markers for three different varieties two of them in Giza 123, one marker for Giza 125 and also one marker in Giza 127. Primer SSR6 produced 7 bands; 5 of them were polymorphic (71\% polymorphism) indicated the presence of three markers for variety Giza 125 . Primer SSR7 produced 3 bands 1 of them was polymorphic (33\% polymorphism); it has one marker for Giza 125. Primer SSR 8 revealed 9 bands 8 of them were polymorphic $(89 \%$ polymorphism) it has six markers in four different varieties two of them in Giza 123 and two in Giza 127, while one marker in each of Giza 124 and Giza 129 varieties. Primer SSR 9 produced 9 polymorphic bands $(100 \%$ polymorphism) indicated three markers for three different varieties Giza 127, Giza 132 and Giza 2000. Primer SSR 10 produced 4 bands 2 of them were polymorphic (50\% polymorphism). Primer SSR 11 produced 8 bands 7 of them was polymorphic $(88 \%$ polymorphism) this primer has two markers in two different varieties Giza 125 and Giza 132. Primer SSR 12 produced 7 bands 4 of them were polymorphic (57\% polymorphism), it produced 2 marker bands with two different varieties Giza 123 and Giza 125.

SSR markers can produce a large number of markers as observed in Giza 125 which was identified by 7 primers at different molecular weight (MW), it produced 14 bands; six of them in primer SSR $1(1470,870,515,405,355$ and $115 \mathrm{bp}$ ), three of them in primer SSR 6 (725, 560 and $460 \mathrm{bp}$ ) and one band in primers SSR 4 (525 bp), SSR 5 (530 bp), SSR 7 (230 bp), SSR 11 (65 bp) and SSR 12 (450 bp). Giza 123 showed five band markers, two of them in primer SSR 5 (550 and $220 \mathrm{bp}$ ), two in primer SSR 8 (580 and $265 \mathrm{bp}$ ) and one band in primer SSR 12 (415 bp). Giza 127 has four marker bands, two of them in primer SSR 8 (190 and $180 \mathrm{bp}$ ), one band in primer SSR 5 (102 bp) also one band in primer SSR 9 (255 bp). Giza 124 recorded two bands in two different primers, SSR 2 (250 bp) and SSR 8 (120 bp). Also Giza132 has two band markers, one of them in primer SSR 9 (205 bp) and the other in primer SSR 11 (560 bp). Giza 129 produced one marker at primer SSR 8 (170bp) as well as Giza 2000 has one marker at primer SSR 9 (200 bp), while no marker could be observed for Giza 126. The previous genetic variability among barely varieties is important to plant breeder in barley breeding programs. Abdellaoue et al. (2007) studied the genetic variation and relationships among 13 local barley accession and the variety Martin using simple sequence repeat (SSR) markers and physiological traits. They showed that a total of 43 bands were generated by 15 SSR primers with an average of 2.6 easily detectable bands per primer. Ramzi et al. (2009) found high level of polymorphism make simple sequence repeats (SSR) the molecular marker of choice for diversity analysis in plant species by using 18 simple sequences repeats (SSR) marker to characterize six Tunisian barley varieties. At the same time, Kadri et al. (2009) studied the genetic variation and relationships among12 local barley genotypes and the varieties Martin and Manel using random amplified polymorphic DNA (RAPD) and simple sequence repeat (SSR), high level of polymorphism was found with both RAPD and SSR markers. El-Awady and EI-Tarras, (2012) indicated that genetic variability within barley landraces is fundamental for barley breeding, they used 16 simple sequence repeats (SSR) markers to characterize six barley landraces from different cultivated regions in Kingdom of Saudi Arabia. A variety of polymerase chain reaction (PCR), based molecular markers is useful tools for the study of genetic diversity. For detection of genetic variation in barley, different classed of molecular markers were used. However, among these classes, the simple sequence repeats (SSR) or microsatellites derived from genomic DNA and amplified fragment length polymorphism (AFLP) have been used separately as well as in combination in many studies (Maeatri et al., 2002, Matus and Hayes, 2002, Turpeinen et al., 2003, Nevo et al., 2005, Chaabance et al., 2009).

\section{Combined analyses for eight barley varieties}

Similarity index and dendrogram across the eight barley varieties under investigation based on SSR analyses are shown in Table 5 and Fig. 3, respectively. The comparison revealed that the 
Table 5. Similarity matrix among the eight barley varieties using SSR analyses

\begin{tabular}{lccccccc}
\hline Variety & Giza 123 & Giza 124 & Giza 125 & Giza 126 & Giza 127 & Giza 129 & Giza 132 \\
\hline Giza 124 & 0.780 & & & & & & \\
Giza 125 & 0.622 & 0.698 & & & & & \\
Giza 126 & 0.712 & 0.841 & 0.727 & & & & \\
Giza 127 & 0.692 & 0.730 & 0.634 & 0.800 & & & \\
Giza 129 & 0.703 & 0.686 & 0.538 & 0.721 & 0.788 & & \\
Giza 132 & 0.685 & 0.696 & 0.545 & 0.767 & 0.738 & 0.852 & \\
Giza2000 & 0.722 & 0.765 & 0.632 & 0.814 & 0.750 & 0.800 & 0.814 \\
\hline
\end{tabular}

$$
\begin{array}{ll}
\text { Giza } & 129 \\
\text { Giza } & 132 \\
\text { Giza } & 2000 \\
\text { Giza } & 124 \\
\text { Giza } & 126 \\
\text { Giza } & 127 \\
\text { Giza } & 123 \\
\text { Giza } & 125
\end{array}
$$

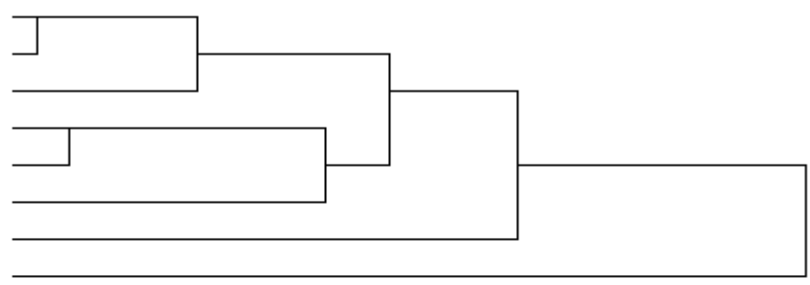

Fig. 3. Dendrogram of the genetic distances among the eight barley varieties based on SSR analyses

most closely related varieties were Giza 129 and Giza 132 (similarity matrix of 0.852 ). The lowest relationships were recorded for varieties Giza 125/ Giza 129 (similarity matrix of .538), followed by varieties Giza 125/ Giza 132 (similarity matrix of 0.545 ). These varieties resulted in two main clusters. One of them involved the variety Giza 125, while the second cluster involved the rest of varieties. The second cluster was divided into two subclusters, one included Giza 123, while the other subcluster involved Giza 127, Giza 126, Giza 124, Giza 2000, Giza 132 and Giza 129. Yang and Ding (2003) found that the dendrogram generated by the SSR matrix agrees better with the genealogy and known pedigree of the barley varieties result. The dendorgrem of genetic distances was constructed based on UPGMA method using midpoint joining procedure of Nei and Li (1979) dissimilarity matrix.

\section{Acknowledgement}

Thankful to Prof A. M. AbdELGhani Department of plant Genetic Resourcess Research (FCRI), ARC, Giza Egypt, for produced maternal and chemical for this research

\section{REFERENCES}

Abdellaoue, R., M.H. Cheikh, M.N. Ban, K.L. Bettaib and H.J. Ben (2007). Simple sequence repeat markers and physiological characterization of some local Tunisian barley accessionl. J. Cell and Mol. Biol., 6 (1): 19-29.

Ali, A.A., M.S.A. Maged, I.A. Ahmad and S.A.E. Mariey (2007). Gentic and molecular studies on barley salt tolerance. Afr. Crop Sci. Conf. Proc., 8: 669-682.

Chaabance, R., M. El Felah, H. Ben Salah, M. Ben Naceur, S. Abdelly, D. Ramia, A. Nada and M. Saker (2009). Molecular characterization of Tunisian barley (Hordeum vulgare L.) genotypes using microsatellites (SSR) markers, Eur. J. Sci, Res., 36: 6-15.

El-Awady, A. and A.E.A. El-Tarras (2012). Genetic diversity of some Saudi barley (Hordeum vulgare L.) landraces based on 
microsatellite markers. Afr. J. Biotechnolo., 11 (21): 4826-4832.

Facciol, P.N.P., A.M. Stanco and V. Terzi (1999). Amplified fragment length polymorphism (AFLP) markers for barley malt finger primting. J. Cereal Sci., 29: 257-260.

Gupta, P.K. and R.K. Varshney (2000). The development and use of microsatellite markers for genetic analysis and plant breeding with emphasis on bread wheat. Euphytica., 113: 163-185.

Kadri, K., R. Abdellawi and M.H. Cheilh (2009). Genetic diversity in barley genetic diversity in local Tunisian barley based on RAPD and SSR analysis. Biol. Diver. and Con. Bio. Di. Con., 2 (1): 27-35.

Karimzadeh, G., G.R. Sharifi-Sirchi, M. Jalali, H. Dehghani and Francis (2006). Soluble proteins induced by low temperature treatment in the leaves of spring and winter wheat varieties. Pak. J. Bot., 38: 1015-1026.

Laemmli, U.K. (1970). Cleavage of structural proteins during the assembly of the head of bacteriophage T4. Nature (London), 227: 680-685.

Maeatri E., A. Malceveschi, A. Massari and N. Marmiroli (2002). Genomics analysis of cultivated barley (Hordeum vulgare L.) using sequence lagged molecular markers, estimates of divergence based on RFLP and PCR markers derived from stress responsive genes and simple sequence repeats SSR, Moi Genel. Geno., 267:186-201.

Masoje, P., B. Myskow and P. Milczarski (2001). Extending a RFLP based genetic map of rey using random amplified polymorphic DNA (RAPD) and isozyme markers. Theoretical Appl. Gen., 102: 1273-1279.

Matus, I.A. and P.M. Hayes (2002). Genetic diversity in three groups of barley germplasm assessed by simple sequence repeats. Gnome, 45: 1095-1106.

Morgante, M., M. Hanafey and W. Powel (2002). Microsatellites are prfentilly associated with non repetitive DNA in plant genomes. Nature Genetic 3: 194-200.
Nei, M. and W. Li (1979). Mathematical model for studying genetic variation in erms of restriction/endonrc 1 eases. P. Natl. Acad. Sci. USA, $76: 5269-5273$.

Nevo, E.A.B., R.C. Meyer, C.A. Hacker and B.P. Foster (2005). Genomic microsatellite adaptive divergence of wild barley be microclimatic stress in evolution canyon. Israel, Bio. J. Linn. Soc., 84: 205-224.

Ramzi, C., E.F. Mouldi, B.S. Hammadi, B.N. Bared, A. Chedly, R. Dalila, N. Ahmad and S. Mahmoud (2009). Molecular Characterization of Tunisian Barley (Hordeum vulgare L.) genotypes using microsatellites (SSRs) markers. Europ. J. Scient. Res., 1: 6-15

Russel, J., J. Fullr, G. Young, B. Thomas, G. Taramino, M. Macaulay R. Waugh and Powell (1997). Discrimination between barley genotypes using microdatellite markers, Genome, 40: 442-450.

Saghai-Maroof, M.A., R.M. Biyashev, GP. Yang, Q. Zhang and R.W. Allard (1994). Extraordinarily polymorphic microsatellite DNA in barley species diversity choromosomal locations and population dynamic. Proc. Nalt. A. Cas. Sci. USA, 91: 5466-5470.

Saker, M., M. Nagchtigall and T. Kuehne (2005). A comparative assessment of DNA fingerprinting by RAPD, SSR and AFLP in genetic analysis of some barley genotypes Egypt J. Genet. and Cytol., 34: 81-97.

Sambrook, J., E.F. Fritsch and T. Maniatis (1989). Molecular cloning. A Laboratory manual, $2^{\text {nd }} E d ., 1$.

Struss, D. and J. Plieske (1998). The use of microsatellite markers for detection genetic diversity in barley populations. Theor. Appel. Gene., 97: 308-315.

Tantz, D. and M. Renz (1984). Simple sequence are ubiquitous repetitive components of eukaryote genomes. Nucleic Acids Res., 12: 4127-4137.

Turpeinen, T., E. Vanhaia, E. Nevo and E. Nissila (2003). AFLP genetic polymorplism in wild barley (Hordeum spontaneum.) population in Iasrael. Theor. Appl. Genet., 106: 1333-1339. 
Von Bothmer R., N. Jacobsen, C. Baden, RB. Jonrgensen and I. Linde-Laursen (1995). An ecogeographical study of the genus Hordeum. Int. Plant Genet. Res., Rome., 29.
Yang, X.G. and d Y. Ding (2003). Analysis of genetic diversity of hordein in wild close relatives. in Chinese with English abstract. J. Fruit Sci., 18: 276-279.

\section{استخدام معلمات SSR للتمييز بين ثمانية أصناف من الشعير رشا يوسف سيد عبد الخالق \\ قسم بحوث تكنولوجيا البذور - معهد بحوث المحاصيل الحقلية ـ مركز البحوث الزراعية ـ الجيزة}

أجريت هذه الدراسة للتمييز بين ثمانية أصناف من الشعير باستخدام تكنيك SSR-PCR و التفريد الكهربى للبروتين

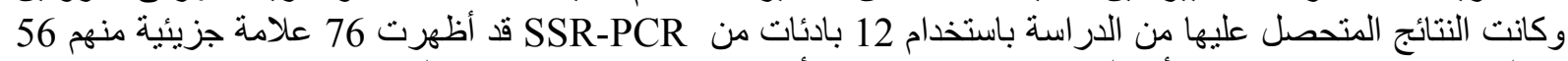

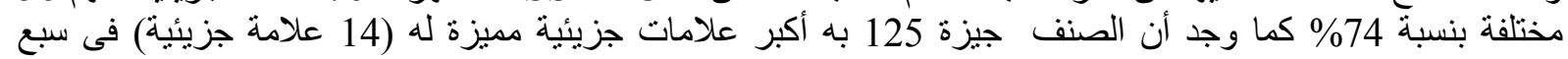

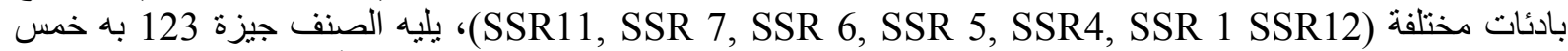

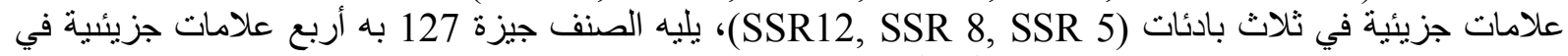

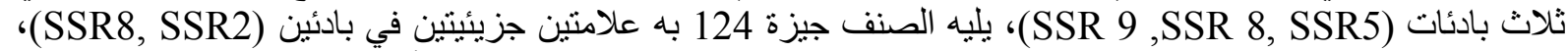

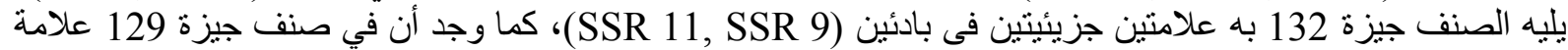

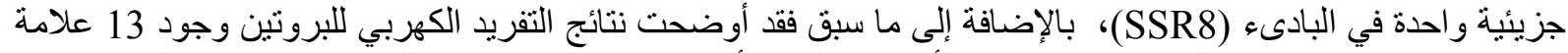

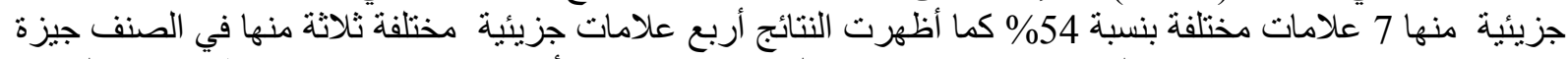

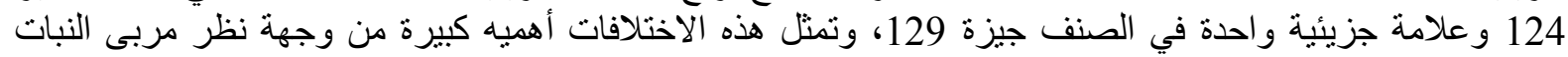
للاستفادة بها في برنامج تحسئة واحدة في الشعير.

أستاذ المحاصيل - كلية التكنولوجيا و التنمية - جامعة الزقازيق.

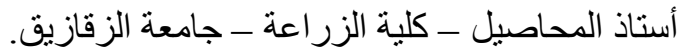

